Caner Tekin

Debating Turkey in Europe 



\section{Caner Tekin}

\section{Debating Turkey}

in Europe

Identities and Concepts 
Dissertation, Fakultät für Geschichtswissenschaften der Ruhr-Universität Bochum Datum der Disputation: 29.11.2016

ISBN: 978-3-11-061168-7

e-ISBN (PDF): 978-3-11-061467-1

e-ISBN (EPUP): 978-3-11-061191-5

Library of Congress Control Number: 2019949239

\section{Bibliographic information published by the Deutsche Nationalbibliothek}

The Deutsche Nationalbibliothek lists this publication in the Deutsche National-

bibliografie;detailed bibliographic data are available on the Internet at http://dnb.dnb.de.

(c) 2020 Walter de Gruyter GmbH, Berlin/Boston

Cover Image: ( ) Jacques-Louis David: The Coronation of Napoln (detail), Halet Efendi Druck und Bindung: $\mathrm{CPI}$ books $\mathrm{GmbH}$, Leck

www.degruyter.com 